\title{
Consumers' Willingness to Pay More for Eco Friendly Products (Green Products) Classification Daily Needs Products
}

\author{
Ida Farida Oesman \\ Universitas Islam Nusantara, Jl. Soekarno Hatta No. 530 Bandung \\ idafaridaoesman@uninus.ac.id
}

\begin{abstract}
Willingness to Pay More (WTPM) for green product is still being debated, because some consumers are behaving that it is the obligation of producers and governments to provide environmentally friendly products, informing them without setting a high price so that buying intentions and consumer confidence arise to buy and consume it. Likewise among millennials, who tend to be more critical in their attitude towards the environment. This study aims to determine the effect of ecolabeling on consumers' willingness to pay more for green products through purchase intentions.
\end{abstract}

Keywords : Ecolabel, Purchase Intention, Willingness to Pay More and Green Product

\section{Introduction}

Over the last few decades, consumer interest in environmentally friendly products has increased [26, 22], which makes them try to apply them in their daily lives in consuming environmentally friendly products better known as green products.. Another term for green product is a product that is sustainable or environmentally friendly products [23]. Research on environmentally friendly marketing and purchasing green products began in the late 1960s, however, major studies emerged in the late 80s [23]. In 1985 green products were introduced in the form of garbage bags, bottles and plastic containers [13] and continues until now [1,35, $11,24,29]$. Green products can be seen from the use of raw materials without chemicals, packaging materials used that are environmentally friendly, and finished products that can be recycled, reused, and biodegradable. Overall it has a low impact on environmental damage [6], has social and environmental responsibilities from the raw material to the production process throughout the product life cycle [9]. Meanwhile, [19] see the understanding of green products from different sides, namely consumer perception. According to him, green products are products that are considered environmentally friendly consumers, both because of the production process, the types of materials or materials used to produce products, packaging, marketing communications and so on, and in this study take the understanding of green products based on consumer perceptions.

Increased consumer awareness of green products about the dangers of synthetic chemicals, especially organic personal care products, daily necessities, has driven the demand for a healthier lifestyle [15]. But in reality although the public's concern for green products increased, they did not buy it immediately because of limited knowledge [16]. One of the efforts made by the company is by labeling the product packaging (ecolabel). Where with the ecolabel can provide specific information related to the product so that consumers can make 
environmentally friendly purchasing decisions [33].

Problems still arise with consumer distrust of ecolabeling. They assume that most companies only stick to the label so that they can charge their customers more without actually making a difference in the environment [16]. Consumers are confused about the criteria of ecolabeling which causes the weakening of consumer confidence in ecolabeling. Erosion of trust and problems in distinguishing ecolabels, influence the attitude of 'green purchase' [8]. Purchasing intentions are also influenced by ecolabels such as "Energy Star" and "EU label" which are intended to reduce electricity bills especially for durable consumer goods, even they can pay higher prices $[8,37]$. This study proves that environmentally friendly labels often help green consumers when they buy [4]. The use of products that are more environmentally friendly can produce a better environment. So, consumer preferences for environmentally labeled products must be investigated to understand the market potential with environmentally friendly products [2].

When green products often involve greater costs, so the price of the product is more expensive than conventional products, creating a social dilemma for consumers to buy the product $[16,3]$. The biggest challenges faced by companies are changes in consumer preferences, suspicion of environmentally friendly advertising claims, unfavorable consumer perceptions of green products, and high costs invested in developing green products [7] , so whether consumers' willingness to pay more for purchasing green products is an important consideration.

\section{Literature Review}

The voluntary environmental labeling program has a history that began with German Blue Angel, in Germany in the late 1970s and its spread began ten years later and the environmental labeling program currently exists in large numbers. Ecolabeling programs have an important role in communication that provides critical quality assurance in communicating product information about environmental impacts [8]. Green labeling is an important tool for green marketing because it helps distinguish green products and non-green products [28].

Definition of ecolabeling is given by several researchers. Bratt et al. [8] explained that ecolabeling is an instrument that has the potential to direct consumers and producers and the entire supply chain in a sustainable direction. The definition of ecolabeling as a way to identify products that are produced in an environmentally friendly manner using many formats that combine graphics, logos and text to attract environmentally conscious consumers [27], a recognizable symbol attached to the product or its packaging, indicating a company, or the performance of an environmentally oriented product [30]. Based on previous literature studies, the definition of ecolabeling in this study is a product label in the form of symbols, signs, certifications that show that the product can be trusted as informed, shows a company, or the performance of an environmentally oriented product. Knowledge, awareness, and information obtained by consumers through ecolabeling can motivate environmentally friendly behavior and consumer purchase intentions [32]. In line with research [21] which says that ecolabeling leads to consumer buying intentions when reading relevant label information.

The effectiveness of ecolabels influences consumers' intention to buy green products when consumer confidence in decision making is still limited [12]. Other research states that consumers do not trust and will not buy green products because most companies only stick to the label so they can charge customers more without actually making a difference in the 
environment. [16]. The results showed that ecolabels influence purchase intentions [9, 10, 12]. This study proves that eco-friendly labels (ecolabels) often help consumers be environmentally friendly when they buy products [4] because packaging is the most interesting factor that initially affects consumers in the purchasing decision process [31]. From this description, I propose the following hypothesis about ecolabeling: H1: Ecolabel is thought to influence consumer purchase intentions.

Willingness To Pay More (WTPM) is operationalized as the willingness of consumers to pay a premium price for the green product version [38]. WTPM occurs when a consumer buys a product willing to pay more than the price of the product due to several things, such as raw materials, manufacturing processes, packaging, and product labels, where in the green product it is part of the determining factor. There are several things that influence consumers to pay more, such as purchasing power, age, gender and social status, also the large percentage of their willingness to pay is very varied in some countries [20]. Besides the knowledge factor [18] a positive attitude towards ecolabeling [36], packaging, labeling, and online shopping experience also have a positive effect [39].

Ecolabeling is important for consumers in understanding, evaluating food safety, health issues, and environmental friendliness of a product [24]. In his study he measured the preferences and willingness of consumers to pay for coffee labeled certification in Taiwan, with certification results that are easily known, organic, the level of certification of products that are environmentally friendly, and shows that fair trade will make consumers willing to pay more. Ecolabeling tends to be an important factor in influencing consumer purchasing decisions, when the price of green products is relatively expensive or of low quality, in other words the product attributes of ecolabels have a dominant role compared to other product attributes [30] when consumers will decide to buy it at a higher price than conventional products.. Research shows the same results, that consumers are willing to pay more for the price of electrocable products, such as 43-inch LED TVs for consumers in Korea [25], and seafood [34]. From this description, I propose the following hypothesis : H2 : Ecolabel is thought to influence the Consumers' Willingness to Pay More.

Knowledge of consumers 'willingness to pay for products can help companies understand consumers' perceptions of prices and meet their expectations. For green products, consumers face a dilemma, because they generally feel the price offered is higher than that charged for conventional products [5]. Higher prices can discourage consumers of buying intentions, especially green products, such as research results [40] which shows that consumers in Chengdu, China have the intention of buying labeled carbon products, but are willing to pay is relatively low. The same was reported by [14] who conducted research on the attitudes of Europeans towards the environment, which showed that in Cypriots and Greece countries had a high purchase intention on green products, but the desire to buy it was low. In contrast to the results of other researchers who show that purchase intention has a significant influence on consumers' willingness to pay more [17]. From this description, I propose the following hypothesis: $\mathrm{H} 3$ : The purchase intention is believed to influence the Consumers' Willingness to Pay More.

The interrelationship between the variables of this study can form a research paradigm, where the willingness to pay more for green products is the implication of ecolabeling, and purchase intention. So the following hypothesis can be made : H4 : Ecolabel is suspected to influence the Consumers' Willingness to Pay More through Purchase Intention. This linkage comes from various previous studies and forms a model of consumer behavior in purchasing products. For more details, the research paradigm will be presented in Figure 1. 


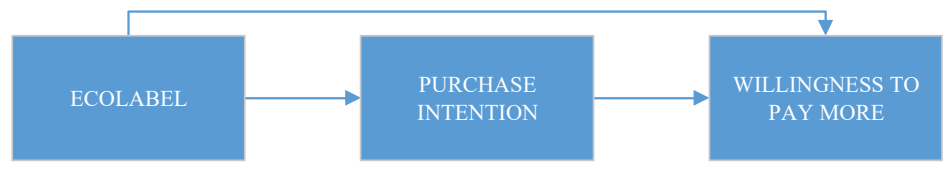

Fig.1. Research Paradigm

\section{Methodology}

\subsection{Data Collection}

Data in this study were collected from Indonesian students in several cities in West Java, which included Bandung, Bogor, Sumedang (Jatinangor). I chose the area for the same reason, that is, there are several well-known tertiary institutions, where the students are young and old millennials, consisting of a variety of different social classes. Given the heterogeneous population, stratified random sampling method was used. More is done in the city of Bandung and Sumedang because there are more universities in the city. Data was collected from September 2019 to December 2019, with a total of 400 respondents who had purchased green products, but there were invalid questionnaires, so the total number of valid questionnaires was 315 .

\subsection{Instrument}

Measure these three research variables, using a five-point Likert Scale. Table 1 summarizes the mean of the research variables.

\section{Result and Discussion}

\subsection{Descriptive Statistics}

Table 1 shows the average Ecolabel variable with an average total of 3.79, the Purchase Intention variable 3.75, and Willingness to Pay More with a total average of 3.66. The lowest average is on the Purchase Intention indicator which is the intention to recommend to others to consume green products. Respondents find it difficult to invite others to consume green products because of the lack of public awareness about green products. This is supported by the education level of respondents who are only at the high school level (currently carrying out an undergraduate level).

Table 1. Descriptive Statistics

\begin{tabular}{llc}
\hline Variables & \multicolumn{1}{c}{ Pernyataan } & Mean \\
\hline Ecolabel & I know a product that has ecolabel & 3.66 \\
& Green Product has ecolabel & 3.81 \\
& Green product material information is clearly stated on the & 3.94 \\
& label & 3.84 \\
& Ecolabel shows good product performance & 3.71 \\
\hline
\end{tabular}




\begin{tabular}{|c|c|c|}
\hline Variables & $\begin{array}{l}\text { Pernyataan } \\
\end{array}$ & Mean \\
\hline $\begin{array}{r}\text { Purchase Intention I } \\
\text { e }\end{array}$ & $\begin{array}{l}\text { I will buy a green product because of my awareness of } \\
\text { environmental issues }\end{array}$ & 4.07 \\
\hline & My intention to buy a green product is very strong & 3.83 \\
\hline & Buying a green product is a good action & 4.27 \\
\hline & I would recommend to others to consume green products & 2.84 \\
\hline Willingness to PayI & I am willing to pay $10 \%$ more for green products & 3.73 \\
\hline $\begin{array}{ll}\text { More } & \mathrm{I} \\
& \mathrm{g}\end{array}$ & $\begin{array}{l}\text { I am willing to increase my monthly expenses by } 10 \% \text { to buy } \\
\text { green products }\end{array}$ & 3.58 \\
\hline
\end{tabular}

The study sample included consumers of different genders, age, education level, and occupation as shown in Table. The profile of respondents was dominated by women, age was 30 years old or below with High School education and as an employee.

Table 2. Respondent Profile

\begin{tabular}{llcc}
\hline Variable & \multicolumn{1}{c}{ Category } & Frequency & Percent (\%) \\
\hline Gender & Female & 150 & 47.62 \\
Age & Male & 165 & 52.38 \\
& 30 years old or below & 226 & 71.75 \\
& 31-40 years old & 53 & 16.83 \\
\multirow{5}{*}{ Education Level } & 41-50 years old & 29 & 9.21 \\
& 51 years old or above & 7 & 2.22 \\
& College Diploma & 182 & 57.78 \\
& Undergraduates & 32 & 10.16 \\
Occupation & 100 & 31.75 \\
& Postgraduate & 1 & 0.32 \\
& College student & 106 & 33.65 \\
& Employee & 146 & 46.35 \\
& Entrepreuneur & 36 & 11.43 \\
& Teacher/Lecturer & 21 & 6.67 \\
& Government employees & 6 & 1.9 \\
\hline
\end{tabular}

Based on Figure 2, Indonesian consumers recognize green products from products that have pictures of green leaves. The reason they like green products is because they are safe for the environment, and the packaging. Their willingness to pay the price of green products is around $0-25 \%$ higher than conventional products.

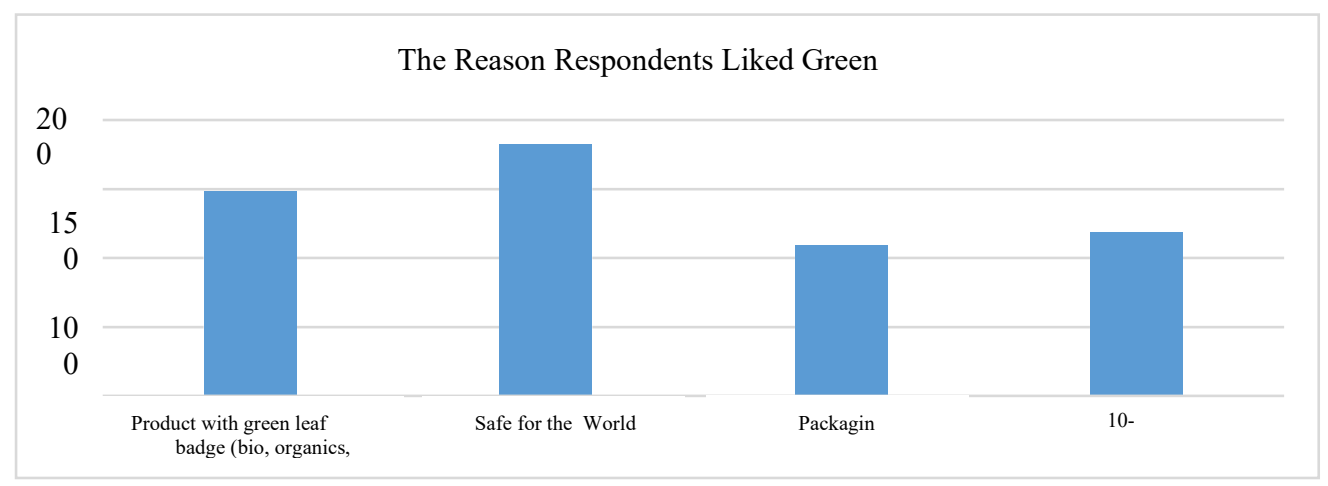

Fig.2. Respondents Profile 
Table 3. Validity and Reliability Test

\begin{tabular}{cccccc}
\hline Variable & No. Item & R Hitung & $\begin{array}{c}\text { Sig. (2- } \\
\text { Tailed) }\end{array}$ & Remarks & $\boldsymbol{\alpha}$ \\
\hline & 1. & 0.501 & 0.000 & Valid & \\
$\mathrm{X}$ & 2. & 0.745 & 0.000 & Valid & \\
& 3. & 0.842 & 0.000 & Valid & 0.815 \\
& 4. & 0.848 & 0.000 & Valid & \\
& 5. & 0.810 & 0.000 & Valid & \\
$\mathrm{Y}$ & 6. & 0.803 & 0.000 & Valid & \\
& 7. & 0.828 & 0.000 & Valid & 0.810 \\
& 8. & 0.746 & 0.000 & Valid & \\
$\mathrm{Z}$ & 9. & 0.818 & 0.000 & Valid & \\
& 10. & 0.940 & 0.000 & Valid & 0.872 \\
& 11. & 0.943 & 0.000 & Valid & \\
\hline
\end{tabular}

Cronbach's alphas and composite reliability for all constructs, showing that all values are greater than the cut-off value of 0.7 proposed by Hair et al.

\subsection{Hypothesis Testing}

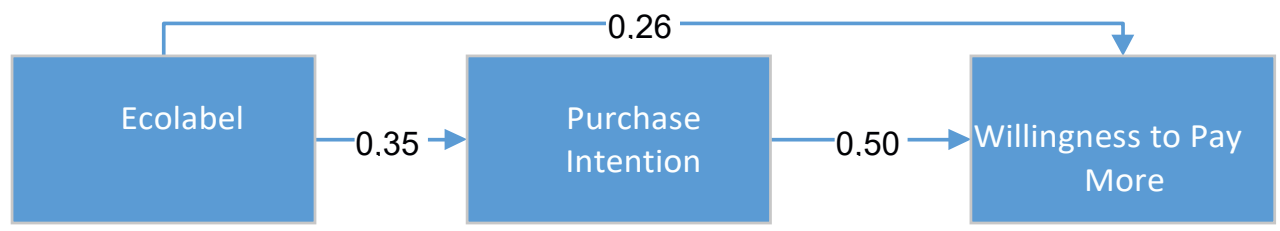

Fig.3. Model Test Results

In order to test the hypotheses, we adopted path analysis. Figure 3 shows the estimation results of the path coefficients of the model. The results show that Ecolabel positively affects Purchase Intention. Moreover, Purchase Intention positively affect willingness to pay more. All hypotheses, namely H1, H2, H3 and H4, are supported.

Table 4. Test of Partial and Simultaneous Models

Model Summary

\begin{tabular}{cc|c|c|c|c}
\hline \multicolumn{6}{c}{ Model Summary $^{\mathbf{b}}$} \\
\hline Model & $\mathrm{R}$ & $\mathrm{R}$ Square & Adjusted R Square & $\begin{array}{c}\text { Std. Error of the } \\
\text { Estimate }\end{array}$ & Durbin-Watson \\
\hline 1 &, $358^{\mathrm{a}}$ &, 128 &, 125 & 2,100 & 1,903 \\
\hline
\end{tabular}

a. Predictors: (Constant), X

b. Dependent Variable: Y

\begin{tabular}{|c|c|c|c|c|c|}
\hline \multicolumn{6}{|c|}{ Coefficients $^{\mathrm{a}}$} \\
\hline Model & \multicolumn{2}{|c|}{$\begin{array}{l}\text { Unstandardized } \\
\text { Coefficients }\end{array}$} & \multirow{2}{*}{$\begin{array}{c}\text { Standardized } \\
\text { Coefficients } \\
\text { Beta }\end{array}$} & \multirow[b]{2}{*}{$\mathrm{T}$} & \multirow[b]{2}{*}{ Sig. } \\
\hline B & & Std. Error & & & \\
\hline (Constant) & 10,865 & ,786 & & 13,831 & ,000 \\
\hline$X$ & ,344 &, 051 & ,358 & 6,775 &, 000 \\
\hline
\end{tabular}


a.Dependent Variable: Y

\begin{tabular}{|c|c|c|c|c|c|c|}
\hline \multicolumn{7}{|c|}{ Coefficients $^{\mathrm{a}}$} \\
\hline & \multicolumn{3}{|c|}{$\begin{array}{l}\text { Unstandardized } \\
\text { Coefficients }\end{array}$} & \multirow[t]{2}{*}{$\begin{array}{c}\text { Standardized } \\
\text { Coefficients Beta }\end{array}$} & \multirow{2}{*}{$\mathrm{t}$} & \multirow{2}{*}{ Sig. } \\
\hline & Model & B & Std. Error & & & \\
\hline \multirow[t]{2}{*}{1} & (Constant) & 4,564 & ,567 & & 8,052 &, 000 \\
\hline & $X$ & 180 & 037 & ,267 & 4,909 & ,000 \\
\hline
\end{tabular}

\begin{tabular}{|c|c|c|c|c|c|c|}
\hline \multicolumn{7}{|c|}{ a. Dependent Variable: $\mathrm{Z}$} \\
\hline & \multicolumn{3}{|c|}{$\begin{array}{l}\text { Unstandardized } \\
\text { Coefficients }\end{array}$} & \multirow{2}{*}{$\begin{array}{c}\text { Standardized } \\
\text { Coefficients } \\
\text { Beta }\end{array}$} & \multirow{2}{*}{$\mathrm{t}$} & \multirow{2}{*}{ Sig. } \\
\hline & Model & B & Std. Error & & & \\
\hline \multirow[t]{2}{*}{1} & (Constant) & 1,625 & ,556 & & 2,925 & ,004 \\
\hline & $\mathrm{Y}$ & 353 & ,034 & ,505 & 10,339 & 000 \\
\hline
\end{tabular}

\begin{tabular}{|c|c|c|c|c|c|c|}
\hline \multicolumn{7}{|c|}{ a. Dependent Variable: Z } \\
\hline Mode & & Sum of Squares & Df & Mean Square & $\mathrm{F}$ & Sig. \\
\hline \multirow{3}{*}{1} & Regression & 203,713 & 2 & 101,857 & 55,736 &, $000^{\mathrm{b}}$ \\
\hline & Residual & 570,172 & 312 & 1,827 & & \\
\hline & Total & 773,886 & 314 & & & \\
\hline
\end{tabular}

a. Dependent Variable: $Z$

b. Predictors: (Constant), Y, X

Willingness the consumers to pay more for green products because of the ecolabel is $12.8 \%$, which are still many other factors that can increase Purchase Intention by $87.2 \%$ such as attitude, lifestyle, and others.

\subsection{Discussion}

Ecolabeling is one of the ways consumers know whether the product is environmentally friendly, so that it can form a pro-environment attitude and he believes in products that are labeled environmentally friendly and can lead to purchase intentions and ultimately decide to buy eco-labeled products. This study evaluates ecolabeling and analyzes the purchase intention of Indonesian consumers on willingness to pay more than green products. The research results show that ecolabel affects only $26.7 \%$ of WTPM, this is due to the lack of consumer knowledge and lack of trust about ecolabel.

\section{References}

[1] Acharya, A. (2020). Eco-Labels. In Green Marketing as a Positive Driver Toward Business Sustainability (pp. 249-274). India: IGI Global. https://doi.org/10.4018/978-1-5225-95588.ch010

[2] Ajzen, I. (1991). The theory of planned behavior. Organ. Behav. Hum. Decis. Process., 50, 179- 
211.

[3] Alhosseini Almodarresi, S. M., Tabataba'i-Nasab, S. M., Bagheri Garabollagh, H., \& Mohammadi, F. (2019). Does citizenship behavior have a role in changing attitude toward green products? International Journal of Management Science and Engineering Management, 14(4), 284-292. https://doi.org/10.1080/17509653.2018.1563874

[4] Amos, C., Pentina, I., Hawkins, T. G., \& Davis, N. (2014). "Natural" labeling and consumers' sentimental pastoral notion. Journal of Product and Brand Management, 23(4-5), 268-281. https://doi.org/10.1108/JPBM-03-2014-0516

[5] Ayadi, N., \& Lapeyre, A. (2016). Consumer purchase intentions for green products: Mediating role of WTP and moderating effects of framing. Journal of Marketing Communications, 22(4), 367-384. https://doi.org/10.1080/13527266.2014.888574

[6] Biswas, A., \& Roy, M. (2015). Leveraging factors for sustained green consumption behavior based on consumption value perceptions: testing the structural model. Journal of Cleaner Production, 95, 332-340. https://doi.org/https://doi.org/10.1016/j.jclepro.2015.02.042

[7] Booi Chen, T., \& Teck Chai, L. (2010). Attitude towards the Environment and Green Products: Consumers' Perspective. Management Science and Engineering, 4(2), 27-39. Retrieved from www.cscanada.net $\% 5$ Cnwww.cscanada.org

[8] Bratt, C., Hallstedt, S., Robèrt, K. H., Broman, G., \& Oldmark, J. (2011). Assessment of ecolabelling criteria development from a strategic sustainability perspective. Journal of Cleaner Production, 19(14), 1631-1638. https://doi.org/10.1016/j.jclepro.2011.05.012

[9] Cai, Z., Xie, Y., \& Aguilar, F. X. (2017). Eco-label credibility and retailer effects on green product purchasing intentions. Forest Policy and Economics, 80(April), 200-208. https://doi.org/10.1016/j.forpol.2017.04.001

[10] Chekima, B., Syed Khalid Wafa, S. A. W., Igau, O. A., Chekima, S., \& Sondoh, S. L. (2016). Examining green consumerism motivational drivers: does premium price and demographics matter to green purchasing?Journal of Cleaner Production, 112, 3436-3450. https://doi.org/https://doi.org/10.1016/j.jclepro.2015.09.102

[11] Choi, D., \& Johnson, K. K. P. (2019). Influences of environmental and hedonic motivations on intention to purchase green products: An extension of the theory of planned behavior. Sustainable Production and Consumption, 18(xxx), 145-155. https://doi.org/10.1016/j.spc.2019.02.001

[12] D'Souza, C., Taghian, M., \& Brouwer, A. R. (2019). Ecolabels information and consumer selfconfidence in decision making: a strategic imperative. Journal of Strategic Marketing, 00(00), 117. https://doi.org/10.1080/0965254X.2019.1636845

[13] Davis, J. J. (1992). Ethics and environmental marketing. Journal of Business Ethics, 11(2), 8187. https://doi.org/10.1007/BF00872314

[14] European Commission. (2008). Attitudes of European Citizens towards the Environment. Special Eurobarometer, 68(2), 1-94. https://doi.org/10.2779/25662

[15] Ghazali, E., Soon, P. C., Mutum, D. S., \& Nguyen, B. (2017). Health and cosmetics: Investigating consumers' values for buying organic personal care products. Journal of Retailing and Consumer Services, 39(June), 154-163. https://doi.org/10.1016/j.jretconser.2017.08.002

[16] Gleim, M. R., Smith, J. S., Andrews, D., \& Cronin, J. J. (2013). Against the Green: A Multimethod Examination of the Barriers to Green Consumption. Journal of Retailing, 89(1), 44-61. https://doi.org/https://doi.org/10.1016/j.jretai.2012.10.001

[17] Gleim, M. R., Smith, J. S., \& Cronin, J. J. (2019). Extending the institutional environment: the impact of internal and external factors on the green behaviors of an individual. Journal of Strategic Marketing, 27(6), 505-520. https://doi.org/10.1080/0965254X.2018.1454498

[18] Hao, Y., Liu, H., Chen, H., Sha, Y., Ji, H., \& Fan, J. (2019). What affect consumers' willingness to pay for green packaging? Evidence from China. Resources, Conservation and Recycling, 141(October 2018), 21-29. https://doi.org/10.1016/j.resconrec.2018.10.001

[19] Johnstone, M. L., \& Tan, L. P. (2015). Exploring the Gap Between Consumers' Green Rhetoric and Purchasing Behaviour. Journal of Business Ethics, 132(2), 311-328. 
https://doi.org/10.1007/s10551-014- 2316-3

[20] Kucher, A., Hełdak, M., Kucher, L., \& Raszka, B. (2019). Factors forming the consumers' willingness to pay a price premium for ecological goods in Ukraine. International Journal of Environmental Research and Public Health, 16(5). https://doi.org/10.3390/ijerph16050859

[21] Kumar,Niraj. Kapoor, S. (2017). Do labels influence purchase decisions of food products? Study of young consumers of an emerging market ". British Food Journal, Vol. 119(Iss 2).

[22] Laureti, T., \& Benedetti, I. (2018). Exploring pro-environmental food purchasing behaviour: An empirical analysis of Italian consumers. Journal of Cleaner Production, 172, 3367-3378. https://doi.org/10.1016/j.jclepro.2017.11.086

[23] Liobikienè, G., \& Bernatonienè, J. (2017). Why determinants of green purchase cannot be treated equally? The case of green cosmetics: Literature review. Journal of Cleaner Production, 162, 109-120. https://doi.org/10.1016/j.jclepro.2017.05.204

[24] Liu, C. C., Chen, C. W., \& Chen, H. S. (2019). Measuring consumer preferences and willingness to pay for coffee certification labels in Taiwan. Sustainability (Switzerland), 11(5), 1-13. https://doi.org/10.3390/su11051297

[25] Min, S. H., Lim, S. Y., \& Yoo, S. H. (2017). Consumers'willingness to pay a premium for ecolabeled LED TVs in Korea: A contingent valuation study. Sustainability (Switzerland), 9(5). https://doi.org/10.3390/su9050814

[26] Paul, J., Modi, A., \& Patel, J. (2016). Predicting green product consumption using theory of planned behavior and reasoned action. Journal of Retailing and Consumer Services, 29, 123-134. https://doi.org/10.1016/j.jretconser.2015.11.006

[27] Rihn, A., Wei, X., \& Khachatryan, H. (2019). Text vs. logo: Does eco-label format influence consumers' visual attention and willingness-to-pay for fruit plants? An experimental auction approach. Journal of Behavioral and Experimental Economics, 82, 101452. https://doi.org/https://doi.org/10.1016/j.socec.2019.101452

[28] Sharma, Nagendra Kumar; Kushwaha, G. S. (2019). Eco-labels: A tool for green marketing or just a blind mirror for consumers. Electronic Green Journal, 1(42). https://doi.org/10.5860/choice.51-2628

[29] Shen, B., Liu, S., Zhang, T., \& Choi, T. M. (2019). Optimal advertising and pricing for new green products in the circular economy. Journal of Cleaner Production, 233, 314-327. https://doi.org/10.1016/j.jclepro.2019.06.022

[30] Song, Y., Qin, Z., \& Yuan, Q. (2019). The impact of eco-label on the young Chinese generation: The mediation role of environmental awareness and product attributes in green purchase. Sustainability (Switzerland), 11(4). https://doi.org/10.3390/su11040973

[31] Tang, E., Fryxell, G. E., \& Clement, S. F. (2008). Visual and Verbal Communication in the Design of Eco- Label for Green Consumer Products. Journal of International Consumer Marketing, 1530(August 2014), 37-41. https://doi.org/10.1300/J046v16n04

[32] Testa, F., Iraldo, F., Vaccari, A., \& Ferrari, E. (2015). Why eco-labels can be effective marketing tools: Evidence from a study on italian consumers. Business Strategy and the Environment, 24(4), 252-265. https://doi.org/10.1002/bse.1821

[33] Thøgersen, J. (2000). Psychological determinants of paying attention to eco-labels in purchase decisions: Model development and multinational validation. Journal of Consumer Policy, 23(3), 285-313. https://doi.org/10.1023/A:1007122319675

[34] Vitale, S., Giosuè, C., Biondo, F., Bono, G. B. G., Sprovieri, M., \& Attanasio, M. (2017). Are People Willing To Pay for Eco-Labeled Wild Seafood? an Overview. European Journal of Sustainable Development, 6(3), 20-28. https://doi.org/10.14207/ejsd 2017.v6n3p20

[35] Wang, J., Tao, J., \& Chu, M. (2020). Behind the label: Chinese consumers' trust in food certification and the effect of perceived quality on purchase intention. Food Control, 108(August 2019). https://doi.org/10.1016/j.foodcont.2019.106825

[36] Wang, L., Wang, J., \& Huo, X. (2019). Consumer's willingness to pay a premium for organic fruits in china: A double-hurdle analysis. International Journal of Environmental Research and Public Health, 16(1). https://doi.org/10.3390/ijerph16010126 
[37] Ward, D. O., Clark, C. D., Jensen, K. L., Yen, S. T., \& Russell, C. S. (2011). Factors influencing willingness- to-pay for the ENERGY STAR ${ }^{\circ}$ label. Energy Policy, 39(3), 1450-1458. https://doi.org/10.1016/j.enpol.2010.12.017

[38] Wei, S., Ang, T., \& Jancenelle, V. E. (2018). Willingness to pay more for green products: The interplay of consumer characteristics and customer participation. Journal of Retailing and Consumer Services, 45(August), 230-238. https://doi.org/10.1016/j.jretconser.2018.08.015

[39] Zhang, B., Fu, Z., Huang, J., Wang, J., Xu, S., \& Zhang, L. (2018). Consumers' perceptions, purchase intention, and willingness to pay a premium price for safe vegetables: A case study of Beijing, China. Journal of CleanerProduction, 197,1498-1507. https://doi.org/https://doi.org/10.1016/j.jclepro.2018.06.273

[40] Zhao, R., Geng, Y., Liu, Y., Tao, X., \& Xue, B. (2018). Consumers' perception, purchase intention, and willingness to pay for carbon-labeled products: A case study of Chengdu in China. Journal of Cleaner Production, 171, 1664-1671. https://doi.org/https://doi.org/10.1016/j.jclepro.2017.10.143 